\title{
Case of Mental Retardation Associated with Aplasia Cutis Congenita and Skull Defect
}

Hyun Chul Cho, MD and Jong Hee Hwang, MD, PhD

Department of Pediatrics, Inje University Ilsan Paik Hospital, Inje University College of Medicine, Goyang, Korea

\section{ABSTRACT}

Aplasia cutis congenita (ACC) is a rare congenital disorder characterized by skin defects involving the epidermis, dermis, subcutaneous tissue, bone, and sometimes dura. It commonly affects the scalp in approximately $70 \%$ of cases, but the neck, trunk, and the extremities can also be affected. ACC can occur either as an isolated condition or associated with other anomalies and congenital syndromes, and it can be acquired either genetically or sporadically. Morbidity and mortality are associated with the defects of skull bone, dura, and other multiple anomalies. We herein report the case of a female infant, with a large scalp defect accompanied by a skull defect noted at birth, who developed mental retardation in the preschool years.

Key Words : Ectodermal dysplasia; Scalp dermatoses; Parietal bone; Infants

서론

선천 피부 무형성(aplasia cutis congenita)은 선천적으로 피부의 전 층에서 결손이 나타 나는 매우 드문 질환으로 출생아 10,000명당 1-3명의 빈도로 발생하고 여자와 남자의 성비는 7:5로 여자에서 빈도가 높은 것으로 되어 있다 ${ }^{1)}$. 발병 부위는 $70 \%$ 에서 두피 특히 두정위(vertex)에서 가장 흔하며 그 외에 목, 몸통, 무릎이나 전완을 포함하는 사지에서도 나타나고 침범 부위는 표 재성 피부, 피하조직, 뽸, 심부 조직의 결손 등 다양하다 ${ }^{2,3)}$. 선천 피부 무형성은 단일 결손으로 발생하기도 하고 다발성 기형을 동반하거나 선천적 증후군과도 연관되어 있고 상염색체 우성 유전이나 가족력을 보이기도 하는데 Frieden은 침범 부위, 동반 기형이나 증후군, 유전 여부 등 에 따라서 9 개의 그룹으로 분류하여 설명하였다 ${ }^{4,5)}$. 이환율과 사망률은 동반된 기형, 두개골이 나 경막의 결손 정도에 따라 증가하게 되는데 ${ }^{(}$, 저자들은 산발적으로 발생하여 정신지체가 동반 된 두개골 결손을 보인 선천 피부 무형성 1례를 경험하였기에 보고하는 바이다.

\section{증례}

환아는 임신 나이 37 주 5일, 출생체중 $2,780 \mathrm{~g}$ 으로 정상질식분만으로 개인 산부인과에서 출
Received: 18 September 2020

Revised: 10 October 2020

Accepted: 28 October 2020

Correspondence to: Jong Hee Hwang, $\mathrm{MD}, \mathrm{PhD}$

Department of Pediatrics, Inje University Ilsan Paik Hospital, Inje University College of Medicine, 170 Juhwa-ro, Ilsanseo-gu, Goyang 10380, Korea

Tel: +82-31-910-7583

Fax: +82-31-910-7108

E-mail: jhhwang@paik.ac.kr

Copyright(c)

By Korean Society of Neonatology.

All right reserved.

This is an Open-Access article distributed under the terms of the Creative Commons At tribution Non-Commercial License (http:// creativecommons.org/licenses/by-nc/4.0), which permits unrestricted non-commercial use, distribution, and reproduction in any medium, provided the original work is properly cited. 
생한 여아로 출생 당시부터 두정부 정중앙에서부터 양쪽 후방 두정 엽에 이르는 $7 \times 6 \mathrm{~cm}$ 의 불규칙한 경계를 가진 타원형의 두피 결손 이 관찰되어 본원 신생아집중치료실로 전원 되었다. 두정부에서 두 정엽까지의 두피 병변은 진피까지 침범된 상태로 중앙부는 거무스 름한 괴사 딱지(eschar)가 형성되어 있었고 주변부는 미만성 발적 이 있었고 두정부에서 전방 전두엽으로는 선상의 불규칙하면서 육 아조직이 혼재된 두피 결손과 모발 손실, 혈관 착색이 관찰되었다 (Figure 1). 산모 나이는 35세로 분만력은 0-0-2-0이었고 3년전 자궁 폴립으로 수술한 과거력 외 약물치료나 단순 포진, 수두 바이러스와 같은 산전 감염 병력이나 태아 단백의 상승은 없었다. 임신 중 시행 한 혈액과 초음파검사는 정상이었고 제대혈에서 시행한 $\mathrm{G}$-스캐닝 유전체검사도 이상은 없었고 친부를 포함한 가족력 상 특이 질환의 병력은 없었다. 입원 시 활력 징후는 혈압 $70 / 51 \mathrm{~mm} \mathrm{Hg}$, 호흡수 42 회/분, 심박수 156 회/분, 체온 $36.4^{\circ} \mathrm{C}$ 로 정상이었고 신체 진찰에서

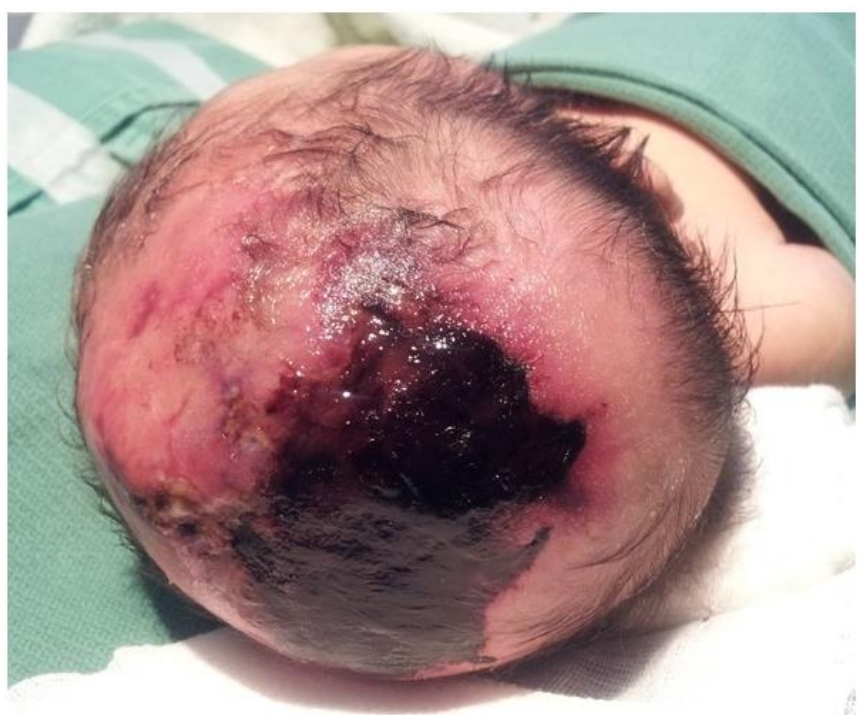

Figure 1. Clinical image shows a skin defect with a dark, dry eschar in the scalp vertex area 3 days after birth.
두피 결손을 제외하고는 이상 소견이나 기형은 관찰되지 않았다. 혈 액검사에서 혈색소 $15.2 \mathrm{~g} / \mathrm{dL}$, 백혈구 $13,220 / \mathrm{mm}^{3}$, 혈소판 290,000/ $\mathrm{mm}^{3}$ 과 전해질은 정상이었고 C-반응단백은 $0.9 \mathrm{mg} / \mathrm{dL}$ 로 증가되었 으나 혈액배양검사에서 동정되는 균은 없었고 심장 초음파검사에 서도 심기형의 소견은 없었다. 단순 두부 사진과 뇌 전산화단층검 사에서 두정엽의 두개골이 부분적으로 소실되어 있거나 얇아져 있 는 소견이 보였으며 그 외 뇌출혈이나 다른 뇌 기형의 이상 소견은 없었다(Figure 2). 치료는 C-반응단백이 정상으로 되고 2차 혈액배 양검사에서 균 동정 여부를 확인할 때까지 1 세대 세파로스포린 항 생제를 정맥으로 8일간 투여하였으며 두피 병변은 죽은 조직 제거 는 출혈을 유발할 수 있어서 시행하지 않고 뮤피로신 연고를 도포 하면서 생리식염수로 충분히 적셔주는 습성 드레싱의 보존적 요법 을 매일 1회 유지하였다. 입원 5일째 두피 병변에 육아조직이 새롭 게 형성되는 소견을 보였고 생후 9일째 습성 드레싱을 포함한 두피 병변 관리에 대한 교육을 보호자에게 시행하고 집에서 자발적으로 관리하기로 하면서 두부의 외상 발생을 예방하는 방법에 대해서는 권고된 지침이 없어서 두부 외상을 주지 않도록 교육한 후에 퇴원하 였다. 생후 40 일째 두피 병변의 3 분의 2 정도까지 건강한 육아조직 이 자라났고(Figure $3 \mathrm{~A}$ ) 생후 3개월째 상피화가 진행되면서 괴사 딱 지는 많이 사라지고(Figure 3B) 생후 9개월째 병변은 모두 상피화 를 형성하면서 두개골 결손이 있었던 가장자리에서부터 단단하게 뼈가 만져지기 시작하였다(Figure 3C). 신경학적 발달 평가에 대해 생후 4 개월부터 본원 재활의학과에서 정기적인 검진을 진행하였고 생후 12 개월까지 정상적인 발달 소견을 보인 상태에서 보호자가 다 른 3차 대학병원에서 시행한 미세배열(microarray)을 포함한 염색 체검사와 뇌 자기공명영상검사가 정상으로 확인이 되자 임의로 외 래 추적검사를 중단하였다. 만 2세까지 또래 아이들과 발달에 차이 가 없었으나 만 3세부터 사회적인 상호작용이 원활하지 않고 언어 표현에 제한이 있어 만 3세 9개월에 개인 재활병원을 방문하여 베 일리검사를 시행하였고 인지발달지수 120 점, 동작 발달지수 91점 으로 경도의 발달 지연으로 재활치료를 시작하였으나 발달 지연이

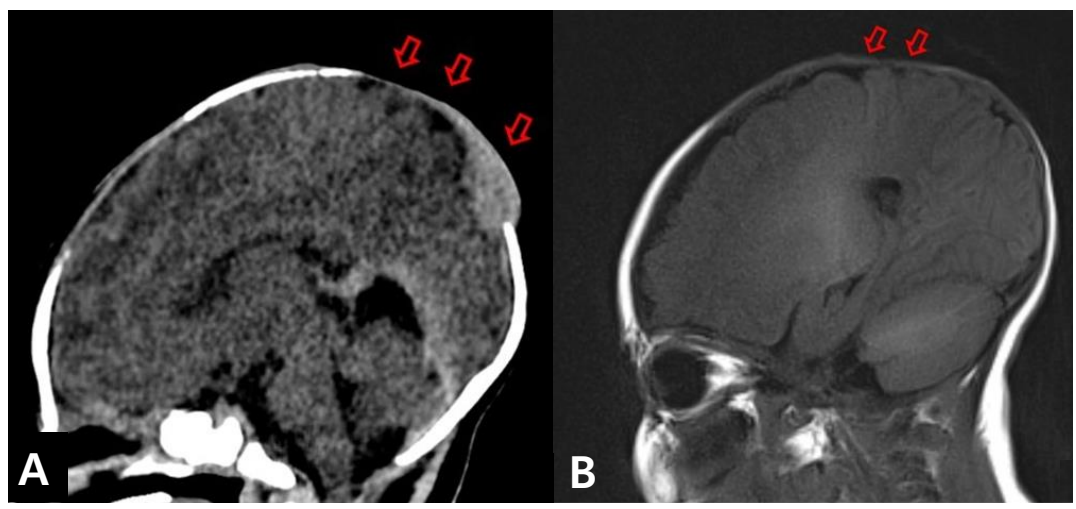

Figure 2. (A, B) Sagittal head computed tomography 5 days after birth shows marked thinning and loss of cortex (red arrows) of the central parietal bone. 


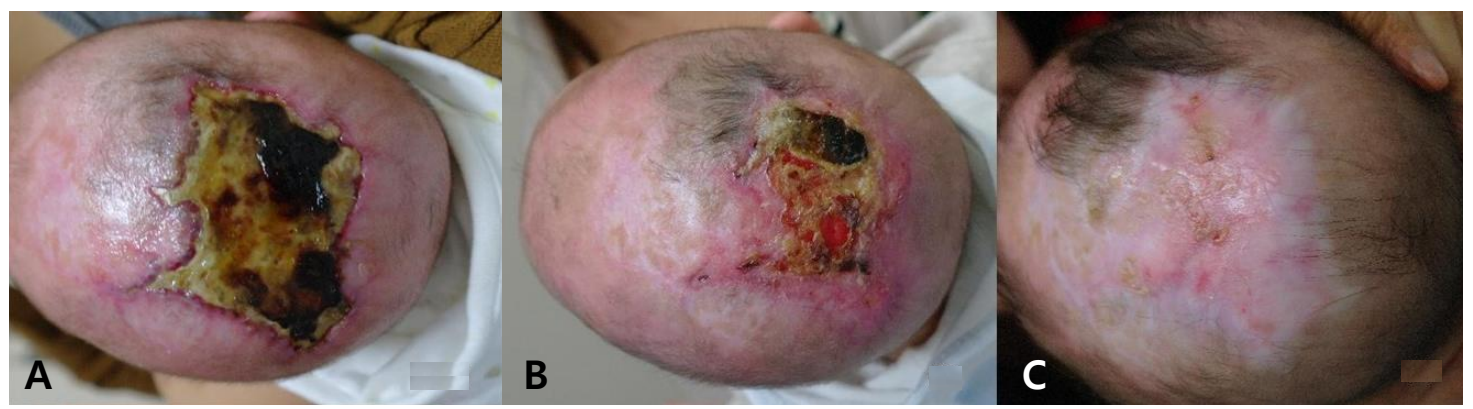

Figure 3. Clinical images show the wound covered with granulation tissue on the 40th day (A), the wound show epithelialization at 3 months (B), and complete healing of the skin wound was achieved at 9 months (C).

더 심화되어 본원 재활의학과를 재방문하였다. 환아는 퇴원 후 뇌 수막염, 뇌염, 뇌혈전색전증, 뇌의 외부 손상 등은 없었으며 뇌 자 기공명영상검사는 12 개월 이후에는 추가적으로 시행하지 않아 검 사를 권유하였으나 보호자가 원하지 않아서 발달검사만 시행하였 으며 본원에서 만 5년 9개월에 시행한 한국 웩슬러 유아 지능검사 (Korean-Wechsler Preschool and Primary Scale of Intelligence)의 전체 지능은 46점, 시각-운동통합 발달검사 Developmental Test of visual-Motor Integration는 3세 수준, 사회성숙도검사(social maturity scale)는 3년 4개월 수준으로 중등도의 정신지체가 진단되어 지 속적으로 재활치료를 진행하고 있다.

\section{고찰}

선천 피부 무형성은 대부분은 두피에서 발병하게 되는데 이런 경 우15\%-30\%에서 두개골과 경막의 결손을 동반하는 것으로 보고하 고 있다 ${ }^{2,7)}$. 병변의 크기는 아주 작은 부위를 침범하는 것부터 전신 의 $90 \%$ 까지 침범하는 등 다양하게 나타나는데 임상 소견은 피부 대 신 얇고 투명한 막으로 덮여 있으며 조기에는 삼출, 궤양의 소견을 보이다 후기에는 괴사 딱지로 덮여 있게 된닥) 본 증례의 환아는 가 장 흔하게 발생하는 두정위 부위에 발병하였고 전두엽과 두정엽까 지 이르는 넓은 범위를 침범하면서 두개골의 결손이 동반된 상태였 으며 조기와 후기의 임상 소견이 혼재되어 있었다.

발생 기전에 대해서는 명확하게 밝혀진 것은 없으며, Stephan 등8) 은 두정위 두피에 발생 빈도가 높은 것과 관련하여 조기 배아형성에 서 태아의 뇌가 성장하는 동안 최대의 장력(biomechanical stretch) 을 받는 부위가 두정위로 두정엽 부분의 두정위가 파열되어 두피 발 생의 빈도가 높을 것이라고 가설을 세웠으나 아직까지 기전과 관련 하여 확정된 보고는 없다. 그러나 선천 피부 무형성을 가진 환자들 을 조사하였을 때 양막 띠(amniotic band), 단순 포진이나 수두 바이 러스에 의한 태내감염, 태아 뇌혈관 사고, 모체의 혈청과 양수에서 아세틸콜린에스테라아제 띠(acetylcholinesterase band)가 양성이 면서 알파 태아단백이 증가한 경우, 코카인, 헤로인, 알코올, 항갑상
선 호르몬제, 미소프로스톨(misoprostol), 메토트렉세이트(methotrexate), 벤조디아제핀, 발프로산, 안지오텐신 전환효소 억제제, 메 티마졸(methimazole)과 같은 기형 유발 물질 등이 위험 요인으로 보 고되고 있다 ${ }^{2,9)}$. 선천 피부 무형성은 산발적으로 또는 가족력이나 유 전적으로 발생하는데 대개 상염색체 우성 유전을 보인다. 동반된 기 형이 없는 단일 결손의 $25 \%$ 에서도 상염색체 우성 유전을 보인다 하 였고 간혹 상염색체 열성 유전이나 성염색체 연관(X-linked) 유전도 보고하고 있다 ${ }^{10,11}$. 병변은 단일 결손으로 나타나거나 다발성 기형 이나 이상, 증후군으로 나타날 수 있는데 구개열, 기관 식도루, 배벽 갈림증, 항문막힘증, 정신지체, 경련, 경직성 마비, 척수막 탈출증, 뇌류, 선천성 심기형, 다낭 신장, 합지증, 만곡족, 수포성 표피박리 증 등이 동반되거나 Adams-Oliver 증후군, Johanson-Blizzard 증후 군, Anderson-Hollister-Szalay 증후군, Golt 증후군, Setleis 증후군 등이나 trisomy 13으로 나타나기도 한다 ${ }^{2,11}$. 본 환아는 선천 피부 무 형성 또는 선천적 기형이나 유전 질환에 대한 가족력은 없었으며 임 신 중에 기형 유발 약물 복용도 없었고 염색체검사에서 이상 소견은 없어서 산발적으로 발생한 것으로 생각되며 정신지체가 동반되어 Frieden의 분류 중 첫 번째 그룹에 해당된다. Frieden은 침범 부위, 동반 기형이나 증후군, 유전 여부 등에 따라서 다발성 기형은 동반 하지 않는 두피 선천 피부 무형성은 그룹 1 로 분류하는데 단일 기형 으로 구개열, 식도기관루, 정신지체, 선천모세혈관확장 대리석피부 증 등이 발생할 수 있다. 사지의 기형을 동반한 두피 선천 피부 무형 성은 그룹 2 , 표피나 기관의 모반을 동반한 두피 선천 피부 무형성은 그룹 3 , 배아형성 기형 위에 중복된 선천 피부 무형성은 그룹 4 , 지상 태아(fetus papyraceous) 또는 태반 경색과 관련된 선천 피부 무형 성은 그룹 5, 수포 없이 사지에만 국한된 선천 피부 무형성은 그룹 6, 특정 기형 유발 물질에 의해 발생한 선천 피부 무형성은 그룹 8 , 기형 증후군과 관련된 선천 피부 무형성은 그룹 9로 분류하였다 ${ }^{4,5)}$.

Lassman과 Sims ${ }^{12)}$ 는 만삭아에서 두정위 두피에 $1.5 \times 2.5 \mathrm{~cm}$ 과 $2.5 \times 2.25 \mathrm{~cm}$ 크기의 두개골 결손을 동반한 선천 피부 무형성이 발 생하였는데 26세 된 만삭아의 어머니가 두정위 부위에 동일한 병변 을 가지고 있었으며 다른 동반된 기형이나 신체적으로는 문제가 없 었으나 지능지수가 62점으로 10 세 수준으로 지연되어 있다고 하였 
다. 어머니의 가족 중에는 선천 피부 무형성이나 다른 기형 그리고 정신지체의 가족력은 없었고 만삭아의 병변은 생후 5 개월에 거의 호전되었으나 신경학적인 추적 검사에 대한 보고는 없었다. 이 연구 는 두피 선천 피부 무형성에서 정신지체를 처음으로 보고한 증례로 Frieden의 그룹 1 로 분류되었다. 또한 Ruiz-Maldonado와 Tamayo ${ }^{13)}$ 는 두피뿐만 아니라 몸통, 양쪽 하지에 선천 피부 무형성이 발생한 만삭아에서 강직마비와 정신지체가 발생하였고 출생 당시 피부 병 변 외에 동반된 기형이나 가족력은 없었다고 보고하였다. 그 외의 외국 보고에서는 다발성 기형의 동반이나 증후군의 동반 없이 선천 적인 피부 병변만 가진 경우에서 정신지체를 보고한 연구는 없었으 며 또한 국내에서는 선천 피부 무형성을 가진 환아에서 동반된 기형 의 갯수나 증후군의 발생 여부와 상관없이 정신지체가 동반된 보고 는 아직까지는 없었다. 따라서 본 연구는 국내에서 선천 피부 무형 성에서 처음으로 정신지체 발생을 보고한 연구로 의미가 있겠다. 국 내외의 연구에서 단일의 두피 선천 피부 무형성에서 정신지체의 보 고가 많지 않는 것에 대해서는 피부 병변으로 소아청소년과 외의 피 부과, 성형외과로 추적 관찰이 집중되면서 신경학적인 발달 평가에 대한 관심이 소홀해질 수 있으며 피부 병변과 신경학적인 발달의 연 관성에 대한 지식의 부족으로 신경학적인 발달에 대한 확인이나 검 사가 이루어지지 못했을 가능성이 있을 것으로 생각된다. 실제로 국 외에서는 장기적으로 신경학적 발달 추적 검사를 진행한 보고는 적 었고 국내에서는 거의 없었다. 따라서 두피에 발생하는 선천 피부 무형성은 작은 크기의 병변을 가진 경우에도 두개골과 경막의 결손 이 동반될 수도 있으며 다발성 기형을 동반하지 않는 경우에도 정신 지체와 같은 신경학적 발달 장애가 발생할 수 있으므로 두개골의 손 상에 대한 정밀 검사와 장기적으로 신경학적 발달에 대한 추적 검사 가 필요할 것이다.

두개골 결손을 동반한 선천 피부 무형성의 치료는 침범 정도에 따 라 보존적인 방법과 수술적 방법 모두를 다양하게 사용하게 된다 ${ }^{14-18)}$. 보존적 치료는 기본적인 창상 관리 원칙에 따라 드레싱과 감 염을 예방하기 위해서 항생제 치료를 병행하는 것으로 권장하고 있 으며 드레싱을 하기 전에 죽은 조직 제거는 여러 논문을 참고하였을 때 초반에 시행한 경우도 있었고 초반에 시행하지 않는 경우에는 환 자의 호전 상태에 따라서 중간에 시행하기도 하였다. 드레싱의 방 법은 다양한 방법을 보고하고 있어서 Canter 등 ${ }^{14)}$ 은 친수성 폴리우 레탄제재 Omiderm (Omikron Scientific Ltd, , Rehovot, Israel)과 비 스무트트리브로 모페네이트 Xeroform (Ovidien, Minneapolis, MN, $\mathrm{USA}$ )이 함침된 거즈를 사용하기도 하였고, 임신 나이 $26^{+5}$ 주, 출생 체중 $600 \mathrm{~g}$ 의 초극소저체중 출생아에서 발생한 $7 \times 6 \mathrm{~cm}$ 크기의 두 피 결손에서 합성 피부 대체제인 Biobrane (Bertek Pharmaceuticals, Sugarland, TX, USA)을 사용한 경우에도 효과적인 치료를 보였다고 하였다 ${ }^{15)}$. 그러나 보존적 치료는 다량 출혈, 뇌수막염, 뇌척수액의 누출, 체액 소실로 인한 탈수 등의 합병증이 증가할 수 있으므로 두
피의 침범 정도를 항상 고려해야 한다. 수술적으로는 분할 또는 전 체 두께 피부 이식, 국소 두피 피판(local scalp flaps), 두개 주위 피판 (pericranial flaps), 자가 골이식을 통한 두개골 성형, 조직 확장, 유 리 피판(free flaps) 등의 다양한 방법으로 재건 치료가 이루어지고 있으며 ${ }^{16,17)}$ 합병증으로는 피판 괴사, 공여 부위 이환, 전신마취의 위 험성 등이 있게 된다 ${ }^{2)}$. 본 증례에서는 상품화된 드레싱제 대신에 뮤 피로신을 환부에 바르고 기존의 거즈에 생리식염수를 충분히 적셔 서 사용한 습성 드레싱을 유지하고 항생제 정맥 투여를 병행하면서 치료를 유지하였다.

두개골 결손을 동반한 선천 피부 무형성의 합병증으로는 감염, 뇌 막염, 출혈, 시상 정맥동혈전증(sagittal sinus thrombosis)이나 경련 이 발생하며 사망률은 $20 \%-55 \%$ 로 높은 것으로 되어있고 ${ }^{19)}$ 특히, 사 망률은 큰 피부 결손을 가지거나 골격을 침범하는 경우에 증가하게 된다 ${ }^{5,7)}$. Harvey 등 ${ }^{17)}$ 도 두정엽에 두개골 결손을 동반한 $4 \times 6 \mathrm{~cm}$ 크 기의 단일 결손이 발병한 신생아에서 시상 정맥동혈전증과 경련의 합병증이 발생하면서 뇌성마비가 동반되었다고 보고하였는데. 단 일기형으로 발생하고 가족적 또는 유전적 원인이 없는 경우에도 정 신지체나 신경학적인 발달장애가 동반되는 경우가 있으므로 두개 골 결손을 가진 선천 피부 무형성이 발생한 신생아에서는 병변 부위 의 치료와 더불어 단기적 또는 장기적인 신경학적 발달에 대한 추적 관찰과 평가가 필요할 것이다.

저자들은 산발적으로 발생한 두개골 결손을 보인 선천 피부 무 형성에서 수술적인 치료 없이 보존적 치료로 두피 병변과 두개골 결손은 호전되었으나 장기적인 발달 검사에서 정신지체가 동반된 Frieden의 1 그룹의 선천 피부 무형성을 국내에서 처음으로 경험하 였기에 보고하는 바이다.

\section{ARTICLE INFORMATION}

\section{Ethical statement}

The study was approved by Institutional Review Board (IRB) of Inje University Ilsan Paik Hospital, Inje University College of Medicine (IRB No. 2020-03-010). Informed consent was waived by the board due to a retrospective nature of our study.

\section{Conflicts of interest}

No potential conflict of interest relevant to this article was reported.

\section{Author contributions}

Conception or design: H.C.C., J.H.H.

Acquisition, analysis, or interpretation of data: H.C.C., J.H.H. 
Drafting the work or revising: H.C.C., J.H.H.

Final approval of the manuscript: J.H.H.

\section{ORCID ID}

Hyun Chul Cho https://orcid.org/0000-0003-3620-3312

Jong Hee Hwang https://orcid.org/0000-0002-4510-0545

\section{Acknowledgments}

None

\section{REFERENCES}

1. Browning JC. Aplasia cutis congenita: approach to evaluation and management. Dermatol Ther 2013;26:439-44.

2. Bharti G, Groves L, David LR, Sanger C, Argenta LC. Aplasia cutis congenita: clinical management of a rare congenital anomaly. J Craniofac Surg 2011;22:159-65.

3. Smartt JM Jr, Kim EM, Tobias AM, Yan AC, Kirschner RE. Aplasia cutis congenita with calvarial defects: a simplified management strategy using acellular dermal matrix. Plast Reconstr Surg 2008; 121:1224-9.

4. Frieden IJ.Aplasia cutis congenita: a clinical review and proposal for classification. J Am Acad Dermatol 1986;14:646-60.

5. Chitnis MR, Carachi R, Galea P. Familial aplasia cutis congenita. Eur J Pediatr Surg 1996;6:100-1.

6. Demmel U. Clinical aspects of congenital skin defects. I. Congenital skin defects on the head of the newborn. Eur J Pediatr 1975;121:21-50.

7. Humphrey SR, Hu X, Adamson K, Schaus A, Jensen JN, Drolet B. A practical approach to the evaluation and treatment of an infant with aplasia cutis congenita. J Perinatol 2018;38:110-7.

8. Stephan MJ, Smith DW, Ponzi JW, Alden ER. Origin of scalp vertex aplasia cutis. J Pediatr 1982;101:850-3.
9. Basterzi Y, Bagdatoglu C, Sari A, Demirkan F. Aplasia cutis cong enita of the scalp and calvarium: conservative wound management with novel wound dressing materials. J Craniofac Surg 2007;18:427-9.

10. Santos de Oliveira R, Barros Juca CE, Lopes Lins-Neto A, Aparecida do Carmo Rego M, Farina J, Machado HR. Aplasia cutis congenita of the scalp: is there a better treatment strategy? Childs Nerv Syst 2006;22:1072-9.

11. Silberstein E, Pagkalos VA, Landau D, Berezovsky AB, Krieger Y, Shoham Y, et al. Aplasia cutis congenita: clinical management and a new classification system. Plast Reconstr Surg 2014;134: 766e-74e.

12. Lassman LP, Sims DG. Congenital midline scalp and skull defect. Arch Dis Child 1975;50:958-60.

13. Ruiz-Maldonado R, Tamayo L. Aplasia cutis congenita, spastic paralysis, and mental retardation. Am J Dis Child 1974;128:699701.

14. Canter HI, Vargel I, Nasir S, Kayikcioglu A. Use of a water-vapour permeable polyurethane film (omiderm) in the non-surgical treatment of aplasia cutis congenita. Scand J Plast Reconstr Surg Hand Surg 2004;38:232-5.

15. Azad S, Falder S, Harrison J, Graham K. An adherent dressing for aplasia cutis congenita. Br J Plast Surg 2005;58:1159-61.

16. Maillet-Declerck M, Vinchon M, Guerreschi P, Pasquesoone L, Dhellemmes P, Duquennoy-Martinot V, et al. Aplasia cutis congenita: review of 29 cases and proposal of a therapeutic strategy. Eur J Pediatr Surg 2013;23:89-93.

17. Harvey G, Solanki NS, Anderson PJ, Carney B, Snell BJ. Management of aplasia cutis congenita of the scalp. J Craniofac Surg 2012;23:1662-4.

18. Rhee ST, Colville C, Buchman SR, Muraszko K. Complete osseous regeneration of a large skull defect in a patient with cutis aplasia: a conservative approach. J Craniofac Surg 2002;13:497-500.

19. Schneider BM, Berg RA, Kaplan AM. Aplasia cutis congenita complicated by sagittal sinus hemorrhage. Pediatrics 1980;66: 948-50. 